\title{
Annual Report ICIMOD 2009
}

2009 Facing the Challenge of Climate Change

The year 2009 brought growing concern about...
Strategic

Programmes

A photograph is perhaps

the most effective way to

describe the strategic...
FOR MOUNTAINS AND PEOPLE

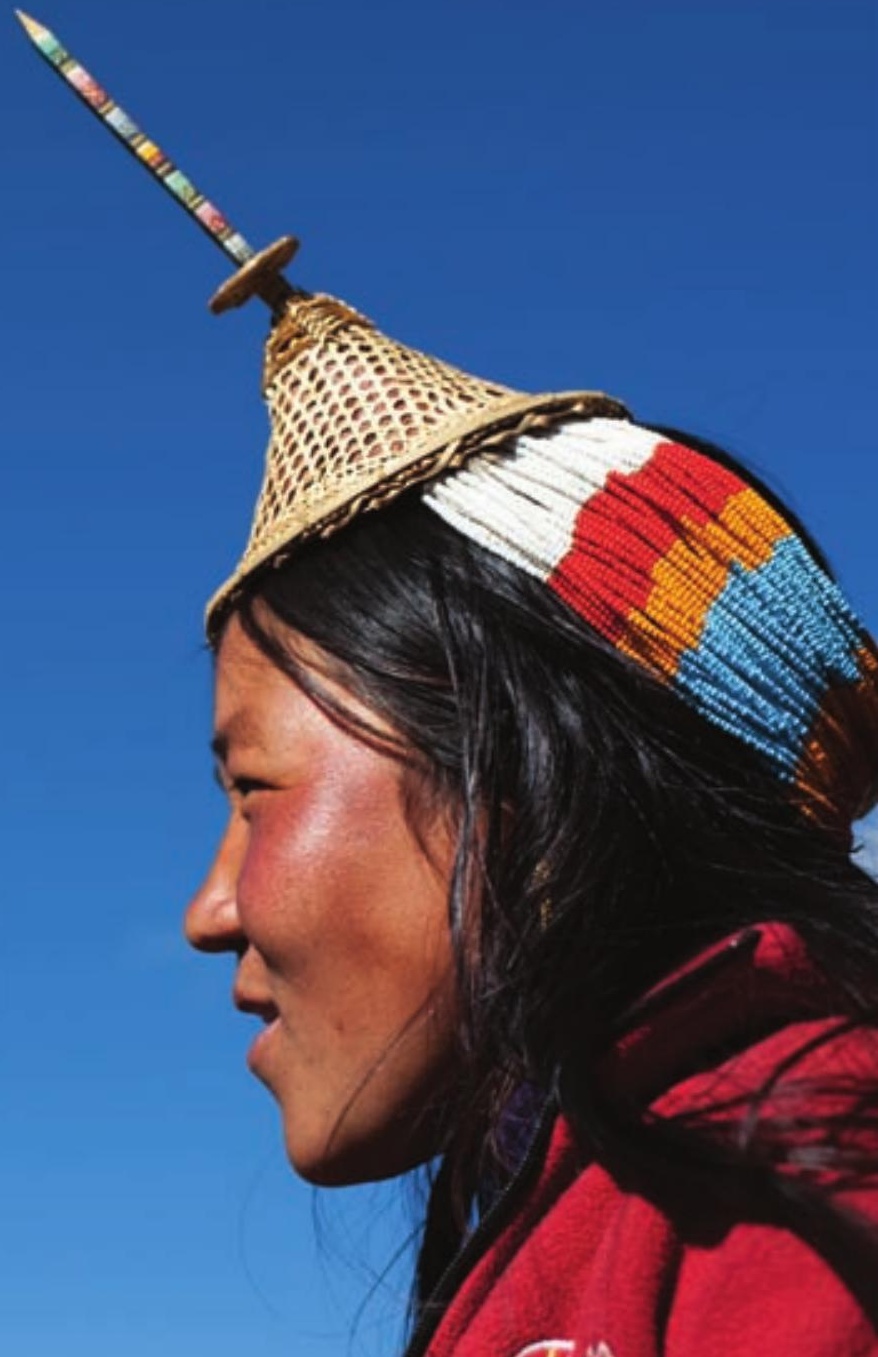


Published by International Centre for Integrated Mountain Development GPO Box 3226, Kathmandu, Nepal

Copyright @ 2010 ICIMOD All rights reserved

ISSN: 10191356

LCCN: sn 92015594

\section{Editorial contact}

ICIMOD Publications, info@icimod.org

\section{Compiled by}

Frances Klatzel (Consultant), Nira Gurung

\section{Production team}

A. Beatrice Murray (Senior Editor)

Punam Pradhan (Design and Layout)

Asha Kaii Thaku (Editorial Assistance)

Printed by Hill Side Press (P) Ltd, Kathmandu, Nepal

This publication is available in electronic form at www.books.icimod.org

\section{Photos:}

Cover: Layap woman, Laya, Bhutan

Inside cover: Floating gardens, Inle lake, Myanmar

Credits:

cover, inside cover, opposite contents, pp 4, 5, 9, 10, 11, 12, 18, 22, 30, 34, 45 Alex Treadway

p 37 APMN; p 25 Farooq Ahmad; p 2 Narendra Bajracharya; pp 28, 36 Nabin Baral; p 24 Dyutiman Choudhary; p 32 Sanjeev Kumar Bhuchar; p 35 Inayatullah Chaudhry; pp 3, 15 Partha Das; p 20 Madhav Prasad Dhakal; pp 16, 17 Sharad Joshi; pp 3, 28 Bhaskar Karky; p 7 Elisabeth Kerkhoff ; p 21 Frances Klatzel; p 15 Deep Raj Rai; p 31 Eklabya Sharma; p 26 Sudas Sharma; p 33 Arun Bhakta Shrestha; p 8 Nani Ram Subedi; pp 2, 6 Robert Zomer

The views and interpretations in this report do not imply the expression of any opinion concerning the legal status of any country, territory, city, or area of its authorities, or concerning the delimitation of its frontiers or boundaries.

This publication may be reproduced in whole or in part and in any form for educational or non-profit purposes without special permission from the copyright holder, provided acknowledgement of the source is made. ICIMOD would appreciate receiving a copy of any publication that uses this publication as a source. No use of this publication may be made for resale or for any other commercial purpose whatsoever without prior permission in writing from ICIMOD.

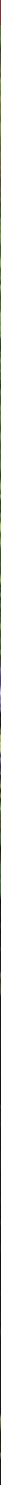


Annual Report 2009 


\section{Contents}

Message from the Director General 2

2009 - Facing the Challenge of Climate Change 5

Strategic Programmes

Water, The Essential Resource $\quad 13$

Promoting the Sustainability of Ecosystem Services 19

Sustainable Livelihoods in a Changing World 23

Managing Knowledge and Communicating $\quad 27$

Reports from the Country Offices and Committees 31

CNICIMOD Secretariat $\quad 31$

Afghanistan Office 33

$\begin{array}{ll}\text { Pakistan Office } & 35\end{array}$

Also at ICIMOD... 36

Mountain Forum Secretariat $\quad 36$

$\begin{array}{ll}\text { Asia-Pacific Mountain Network } & 37\end{array}$

Mountain Partnership Secretariat 38

South Asian Network for Development and Environmental Economics 38

\section{Publications, People and Finances}

$\begin{array}{ll}\text { Publications } & 39\end{array}$

Board of Governors $\quad 44$

Staff $\quad 46$

$\begin{array}{ll}\text { Financial Report } & 48\end{array}$

ICIMOD Members, Sponsors and Funding Partners $\quad 54$ 